\title{
Metabolism of Asparagine and Glutamine in Growing Rats at Various Dietary Protein Levels
}

\author{
Hideyuki Tanaka, Kiyotaka Takahashi, Mitsuhiro Mori \\ and Masaji OGuRA \\ Department of Agricultural Chemistry, Faculty of Agriculture, \\ Utsunomiya University, Mine-350, Utsunomiya 321, Japan \\ Received February 20, 1991
}

\begin{abstract}
The metabolic fate of the carbon skeletons of $\mathrm{L}-\left[\mathrm{U}_{-}{ }^{14} \mathrm{C}\right]$ asparagine and $\mathrm{L}-\left[\mathrm{U}-{ }^{14} \mathrm{C}\right]$ glutamine was investigated in growing rats fed with diets containing different percentages of protein calories $(0,5,10,15$ and $30 \mathrm{PC} \%)$ at $4100 \mathrm{kcal}$ of metabolizable energy per $\mathrm{kg}$ of diet.

The incorporation of ${ }^{14} \mathrm{C}$ into the body protein $12 \mathrm{hr}$ after injecting ${ }^{14} \mathrm{C}$-labeled asparagine was high in the lower $\mathrm{PC} \%$ groups, about $60 \%$ of the dose being recovered, but the value decreased in the higher $\mathrm{PC} \%$ groups. Most of the radioactivity incorporated into the tissue protein was present in the aspartic acid and/or asparagine fraction. The pattern of expired ${ }^{14} \mathrm{CO}_{2}$ production was in inverse relation to that of ${ }^{14} \mathrm{C}$ incorporation into the body protein. The incorporation of ${ }^{14} \mathrm{C}$-glutamine into the body protein was markedly less in all the dietary groups, but the expired ${ }^{14} \mathrm{CO}_{2}$ production was extremely high, more than $\mathbf{7 0} \%$ of the dose being oxidatively degraded. These results show that the metabolic response of glutamine to dietary protein well resembles that of glutamic acid, aspartic acid or alanine, but markedly differs from that of asparagine, which is preferentially used for body protein synthesis, especially during protein depletion.
\end{abstract}

Both asparagine and glutamine are dicarboxylic amino acid amides, and need not be supplied for the growth of rats because of the asparagine and glutamine synthetase activities in rat tissue. ${ }^{1)}$ However, several workers have claimed that the maximum growth of rats is dependent on dietary asparagine during the early phases of development, since endogenous synthesis of this amino acid from aspartic acid is inadequate to meet all of the animal's needs. ${ }^{2-6)}$ Breuer et al. have demonstrated the improved growth of young rats by the addition of asparagine to an amino acid diet, ${ }^{3)}$ and a higher conservation of asparagine carbon in the bodies of rats compared with aspartic acid carbon when the labeled amino acid was given. ${ }^{4)}$ Although it is unlikely that asparagine has a major function other than that of a protein constituent in the animal, glutamine plays a central role in nitrogen metabolism and an important vehicle for transporting nitrogen from muscle to intestine and kidney tissue. ${ }^{1,7)}$

In the previous experiments, we investigated the metabolic fate of the carbon skeletons of individual ${ }^{14} \mathrm{C}$-labeled amino acids in growing rats fed on diets with a graded level of purified whole egg protein. ${ }^{8-17)}$ It was found that the carbon skeletons of the nonessential amino acids, alanine, aspartic acid and glutamic acid, were markedly oxidized to expired carbon dioxide even with protein depletion, but a considerable amount of glycine, serine and proline was incorporated in to the body protein. In contrast, the carbon skeletons of essential amino acids were preferentially used for body protein synthesis. The results also suggested that the metabolic fate of each of these amino acids was quite different, one from another, showing a systematic pattern that is peculiar to their essentiality and catabolic activity. In this paper, the experiments were extended to include the metabolic fate of asparagine and glutamine in the bodies of growing rats fed with diets of various protein to energy ratios, by measuring the distribution of radioactivity from the ${ }^{14} \mathrm{C}$-labeled amino acids to the expired 
carbon dioxide, urine, body protein, body lipid and body soluble fractions. There are apparent differences in the metabolic pattern of asparagine and glutamine in rats. Distinguishable metabolic aspects of asparagine are pointed out compared with those of aspartic acid, which was demonstrated in our previous paper. ${ }^{12)}$

\section{Materials and Methods}

Animals and diets. Male Wistar rats weighing about $85 \mathrm{~g}$ were used in all experiments. The animals were housed in individual stainless wire-mesh cages at $23 \pm 1^{\circ} \mathrm{C}$ in a temperature-controlled room with a $12 \mathrm{hr}$ light, $12 \mathrm{hr}$ dark cycle, the dark cycle being from 6:00 to 18:00. Food and water were given ad libitum for 10 days. The experimental diets contained $0,55,111,166$ and $332 \mathrm{~g}$ of purified whole egg protein ${ }^{18)}$ per $\mathrm{kg}$, as the $0,5,10,15$ and $30 \mathrm{PC} \%$ diets, respectively. All the diets contained $100 \mathrm{~g}$ of lard, $50 \mathrm{~g}$ of cellulose powder, $40 \mathrm{~g}$ of salt mixture, $10 \mathrm{~g}$ of vitamin mixture, and enough corn starch to complete $1 \mathrm{~kg}$, as described previously. ${ }^{8)}$ The protein calorie percentage (PC\%) means the proportion of metabolizable energy of dietary protein to the total metabolizable energy of the diet, ${ }^{19}$ i.e. $4100 \mathrm{kcal}$ per $\mathrm{kg}$ of diet in this experiment.

Isotope experiments. The amino acids injected were $\mathrm{L}-\left[\mathrm{U}-{ }^{14} \mathrm{C}\right]$ asparagine $(150 \mathrm{mCi} / \mathrm{mmol})$ and $\mathrm{L}-\left[\mathrm{U}-{ }^{14} \mathrm{C}\right] \mathrm{glu}-$ tamine $(288 \mathrm{mCi} / \mathrm{mmol})$, which were purchased from Amersham, Japan. On the last day of feeding, the rats were starved for $9 \mathrm{hr}$, from $12: 00$ to $21: 00$, and then given the same experimental diets for $3 \mathrm{hr}$, from $21: 00$ to $24: 00$. After this feeding, ${ }^{14} \mathrm{C}$-labeled amino acid in a saline solution was administered by intraperitoneal injection. The standard dosage was $3.20 \mu \mathrm{Ci} / 0.4 \mathrm{ml} / 100 \mathrm{~g}$ of body weight for ${ }^{14} \mathrm{C}$-asparagine and $3.06 \mu \mathrm{Ci}$ for ${ }^{14} \mathrm{C}$-glutamine. Immediately after the injection, each animal was placed in a glass metabolism apparatus, and offered only water. The expired $\mathrm{CO}_{2}$ was collected in a mixture of monoethanolamine and ethyleneglycol monomethyl ether $(1: 2$, $\mathrm{v} / \mathrm{v}$ ) for $12 \mathrm{hr}$, and the radioactivity was measured by the method of Jeffay and Alvarez. ${ }^{20)}$ Urine was collected in $5 \%$ acetic acid for $12 \mathrm{hr}$, and the radioactivity was measured in an NT (Nonion-toluene) scintillation solution containing $4 \mathrm{~g}$ of PPO per liter of 3 parts of nonylphenoxy polyethoxy ethanol and 7 parts of toluene. ${ }^{21)}$

Analyses. The animals were killed by decapitation $12 \mathrm{hr}$ after administering the isotopes. The liver was removed, and the shed blood was combined with the carcass. The carcass and liver were homogenized and analyzed for radioactivity in their major components such as the protein, lipid and soluble fractions, details of which were described in our previous paper. ${ }^{13}$ ) A portion of the homogenates was with a chloroform-methanol (C-M) mixture $(2: 1, v / v)^{22)}$ to obtain the lipid fraction, and the residue was then extracted with cold $10 \%$ trichloroacetic acid (TCA). The TCA extract was combined with the upper-phase solution by Folch's washing method to obtain the soluble fraction of the sample. The TCA-insoluble residue was dissolved in $2 \mathrm{~N} \mathrm{NaOH}$ as the protein fraction. The radioactivity of the lipid fraction was measured in a toluene scintillation solution containing $4 \mathrm{~g}$ of PPO and $0.5 \mathrm{~g}$ of POPOP per liter of toluene. The radioactivity of the protein and soluble fractions was measured in an NT scintillation solution as already described, the radioactivity being measured with a liquid scintillation spectrometer (Packard, 3255). The efficiency of the counting system was estimated for each sample by an external standard ratio method.

In the experiment for ${ }^{14} \mathrm{C}$-asparagine, the tissue protein was hydrolyzed with $6 \mathrm{~N} \mathrm{HCl}$ at $110^{\circ} \mathrm{C}$ for $24 \mathrm{hr}$ in a sealed tube, and amino acids in the hydrolysate were analyzed in an amino acid analyzer (JEOL, 6AHS). The effluent of the column was divided into two streams, the first one being used to detect the amino acids by the ninhydrin reaction and the second for measuring the radioactivity.

Statistical analyses. The results were tested by an analysis of variance, and Tukey's procedure for multiple comparisons was used to evaluate the statistical significance with a probability level of $0.05 .^{23)}$

\section{Results}

The growth curves of the 10,15 and $30 \mathrm{PC} \%$ groups were almost linear, while that in the 5 $\mathrm{PC} \%$ group was slightly retarded during the early days of the experimental period (Fig. 1). The body weight gain reached its approximate maximum at around $10 \mathrm{PC} \%$ in the diet. The

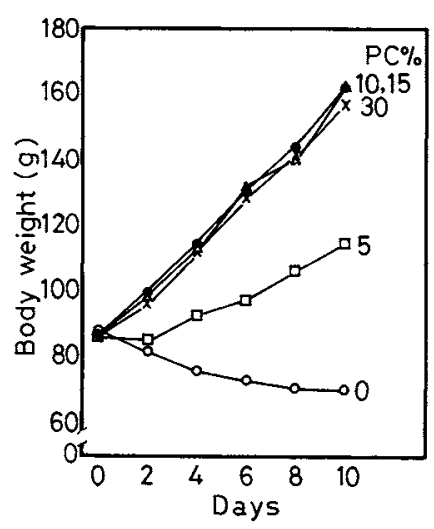

Fig. 1. Growth Curves of Rats Fed on Diets of Various Protein Calorie Percentages. 
results of the growth experiments were essentially identical with those obtained by our previous work. ${ }^{9)}$

The recovery of radioactivity in the expired

Table I. RECOVERY OF RADIOACTIVITY IN EXPIRED $\mathrm{CO}_{2}$ AND URINE FROM L-[U- $\left.{ }^{14} \mathrm{C}\right]$ GLUTAMINE AND L-[U- $\left.{ }^{14} \mathrm{C}\right]$ Asparagine in Rats Fed with Diets of Various Protein Calorie Percentages

The values are mean $t$ standard errors for four rats. Tukey's test was taken as the criterion of statistical significance with a probability level of 0.05 .

\begin{tabular}{|c|c|c|c|c|}
\hline \multirow{2}{*}{$\begin{array}{c}\text { Dietary } \\
\text { group } \\
(\mathrm{PC} \%)\end{array}$} & \multicolumn{2}{|c|}{${ }^{14} \mathrm{C}$-Asparagine } & \multicolumn{2}{|c|}{${ }^{14} \mathrm{C}$-Glutamine } \\
\hline & \multicolumn{4}{|c|}{$(\%$ of the injected dose $)$} \\
\hline 0 & $27.2 \pm 0.7$ & $4.4 \pm 0.4$ & $82.8 \pm 3.1$ & $3.6 \pm 0.7$ \\
\hline 5 & $19.7 \pm 0.8$ & $4.5 \pm 0.4$ & $74.1 \pm 0.8$ & $4.0+1.0$ \\
\hline 10 & $17.9 \pm 0.2$ & $5.0 \pm 0.2$ & $70.5 \pm 1.4$ & $6.3 \pm 0.8$ \\
\hline 15 & $21.2 \pm 0.5$ & $5.0 \pm 0.4$ & $69.0 \pm 1.6$ & $6.1 \pm 0.3$ \\
\hline 30 & $27.4 \pm 0.5$ & $5.9 \pm 0.3$ & $70.1 \pm 0.5$ & $8.1 \pm 0.2$ \\
\hline $\begin{array}{c}\text { Diff. } \\
(p<0.05)\end{array}$ & 2.8 & NS & 6.9 & 2.7 \\
\hline
\end{tabular}

NS, not significant. carbon dioxide and urine from both the labeled amino acids is shown in Table I. The distribution of the radioactivity in the protein, lipid and soluble fractions of the carcass and liver is shown in Table II. As has been pointed out previously, no drastic change in pool size of the amino acid in the tissues was induced by the injecting ${ }^{14} \mathrm{C}$-labeled asparagine or glutamine, since only a trace of the labeled amino acid was used. The total recovery percentages of radioactivity in the $0,5,10$, 15 and $30 \mathrm{PC} \%$ groups were $98.2,95.4,91.0$, 86.5 and $85.4 \%$, respectively, for the labeled asparagine, and 106.6, 105.5, 103.8, 103.6 and $104.5 \%$ for the labeled glutamine (means of four rats in each group).

The production of expired ${ }^{14} \mathrm{CO}_{2}$ for $12 \mathrm{hr}$ after injecting the labeled asparagine decreased gradually with increasing dietary protein level from 0 to $10 \mathrm{PC} \%$, but thereafter it increased in the rats fed on the higher $\mathrm{PC} \%$ diet. The expired ${ }^{14} \mathrm{CO}_{2}$ production from labeled glutamine was significantly greater than that from

Table II. Recovery of Radioactivity in the Protein, Lipid and Soluble Fractions of Carcass and Liver from L- $\left[\mathrm{U}_{-}{ }^{14} \mathrm{C}\right]$ Glutamine and L- $\left[\mathrm{U}-{ }^{14} \mathrm{C}\right]$ Asparagine in Rats Fed with Diets of Various Protein Calorie Percentages

The values are mean \pm standard errors for four rats. Tukey's test was taken as the criterion of statistical significance with a probability level of 0.05 .

\begin{tabular}{|c|c|c|c|c|c|c|}
\hline \multirow{2}{*}{$\begin{array}{l}\text { Dietary } \\
\text { group } \\
(\mathrm{PC} \%)\end{array}$} & \multicolumn{2}{|c|}{ Protein } & \multicolumn{2}{|c|}{ Lipid } & \multicolumn{2}{|c|}{ Soluble fraction } \\
\hline & \multicolumn{6}{|c|}{ ( $\%$ of the injected dose) } \\
\hline \multicolumn{7}{|c|}{${ }^{14} \mathrm{C}$-Asparagine } \\
\hline 0 & $54.2 \pm 1.0$ & $5.2 \pm 0.2$ & $2.0 \pm 0.3$ & $0.1 \pm 0.02$ & $4.6 \pm 0.2$ & $0.5 \pm 0.12$ \\
\hline 5 & $59.2 \pm 1.1$ & $5.7 \pm 1.1$ & $2.2 \pm 0.2$ & $0.1 \pm 0.01$ & $3.8 \pm 0.2$ & $0.3 \pm 0.03$ \\
\hline 10 & $57.0 \pm 0.9$ & $4.2 \pm 0.3$ & $1.7 \pm 0.1$ & $0.3 \pm 0.17$ & $4.3 \pm 0.5$ & $0.4 \pm 0.02$ \\
\hline 15 & $48.4 \pm 2.0$ & $4.7 \pm 0.2$ & $1.7 \pm 0.1$ & $0.1 \pm 0.01$ & $5.0 \pm 0.7$ & $0.3 \pm 0.03$ \\
\hline 30 & $40.7 \pm 1.8$ & $4.5 \pm 0.5$ & $1.7 \pm 0.3$ & $0.2 \pm 0.02$ & $4.4 \pm 0.2$ & $0.7 \pm 0.19$ \\
\hline $\begin{array}{l}\text { Diff. } \\
(p<0.05)\end{array}$ & 7.2 & NS & NS & NS & NS & NS \\
\hline \multicolumn{7}{|c|}{${ }^{14} \mathrm{C}$-Glutamine } \\
\hline 0 & $13.3 \pm 1.6$ & $0.4 \pm 0.1$ & $3.1 \pm 0.4$ & $0.2 \pm 0.04$ & $2.3 \pm 0.2$ & $1.0 \pm 0.2$ \\
\hline 5 & $18.6 \pm 0.5$ & $0.5 \pm 0.1$ & $4.5 \pm 0.8$ & $0.2 \pm 0.05$ & $2.4 \pm 0.2$ & $1.1 \pm 0.1$ \\
\hline 10 & $19.4 \pm 0.3$ & $0.5 \pm 0.02$ & $3.0 \pm 0.2$ & $0.2 \pm 0.04$ & $2.3 \pm 0.1$ & $1.7 \pm 0.2$ \\
\hline 15 & $20.5 \pm 0.7$ & $0.5 \pm 0.1$ & $2.7 \pm 0.3$ & $0.2 \pm 0.05$ & $3.1 \pm 0.5$ & $1.5 \pm 0.1$ \\
\hline 30 & $17.8 \pm 0.6$ & $0.7 \pm 0.1$ & $2.7 \pm 0.2$ & $0.1 \pm 0.01$ & $2.8 \pm 0.2$ & $2.2 \pm 0.1$ \\
\hline $\begin{array}{l}\text { Diff. } \\
(p<0.05)\end{array}$ & 3.4 & 0.3 & NS & NS & NS & 0.6 \\
\hline
\end{tabular}

NS, not significant. 
asparagine over the whole range of dietary protein calorie percentages, and even on a protein-free diet, glutamine carbon was markedly oxidized to carbon dioxide (about $83 \%$ of the dose). The pattern of expired ${ }^{14} \mathrm{CO}_{2}$ production was in inverse relation to that of the ${ }^{14} \mathrm{C}$ incorporation into the body protein fraction (the sum of carcass and liver). The urinary excretion of radioactivity from the labeled asparagine was about $5 \%$ of the dose during a 12-hr period, and there was no significant difference among the dietary groups. However, when labeled glutamine was administered, the urinary excretion of the label increased with increasing dietary protein calorie percentage, about $8 \%$ of the dose being recovered in the $30 \mathrm{PC} \%$ group.

The incorporation of radioactivity from the labeled asparagine into the carcass protein was high in the 0 and $10 \mathrm{PC} \%$ groups (more than $50 \%$ of the dose), but it decreased significantly with increasing dietary protein level to $30 \mathrm{PC} \%$. The incorporation of labeled asparagine into the liver protein remained unchanged over all the dietary groups. The conversion of asparagine carbon into the carcass lipid was about $2 \%$ of the injected dose, while the recovery of the label in the carcass soluble fraction was about 4 to $5 \%$. No significant difference was observed among the dietary groups for the recovery percentages of radioactivity in both the lipid and soluble fractions. On the other hand, the incorporation of labeled glutamine into the carcass protein was low in the $0 \mathrm{PC} \%$ group, and then slightly but significantly increased in the higher PC\% groups (about $20 \%$ of the dose). The incorporation of labeled glutamine into the liver protein was very low. Thus, the incorporation of labeled glutamine into the carcass and liver protein was much less than that of labeled asparagine. The conversion of glutamine carbon into the carcass lipid was somewhat higher than that of asparagine among all the dietary groups. The recovery of radioactivity in the soluble fraction of the carcass and liver was about 1 to $3 \%$ of the dose, and there was no significant difference among the dietary groups.

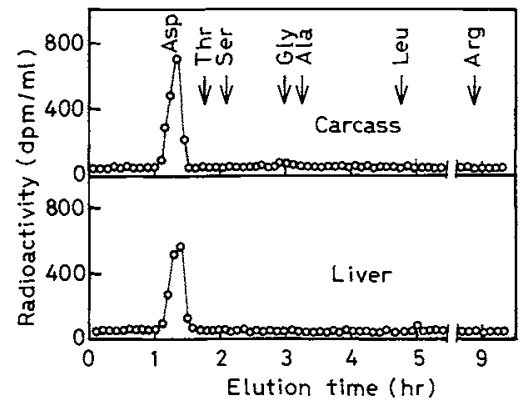

Fig. 2. Distribution of Radioactivity in Each Amino Acid Fraction from Tissue Protein Hydrolysates after Injecting $\mathrm{L}-\left[\mathrm{U}-{ }^{14} \mathrm{C}\right]$ Asparagine into Rats Fed on Diets with Various Protein Calorie Percentages.

The amino acids were analyzed in an automatic amino acid analyzer using a lithium citrate buffer.

In the experiment with ${ }^{14} \mathrm{C}$-asparagine, the distribution of radioactivity in each amino acid fraction after hydrolyzing the carcass and liver protein was examined. Typical elution patterns for the carcass and liver protein hydrolysates in the $15 \mathrm{PC} \%$ group are shown in Fig. 2. A large peak of radioactivity was detected only in the aspartic acid fraction, and only negligible quantities of the label were detected in the other amino acid fractions. Since asparagine in the tissue protein was converted to aspartic acid by hydrolysis, the amounts of ${ }^{14} \mathrm{C}$ incorporated as asparagine per se coluld not be determined. When the protein hydrolysate from a pooled sample of each dietary group was analyzed in the same manner, no difference in the elution patterns of the label was observed among the dietary groups. Because of the small amount of the label incorporated into the tissue protein from ${ }^{14} \mathrm{C}$-glutamine, the distribution was not examined for this amino acid.

\section{Discussion}

In our previous studies, the matabolic fate of the carbon skeletons of 18 individual amino acids was examined in growing rats in relation to nutritional data on the protein and energy metabolism. The metabolic aspects of these amino acids are classified into three groups. The first one includes nonessential amino acids which are rapidly degraded to expired carbon 


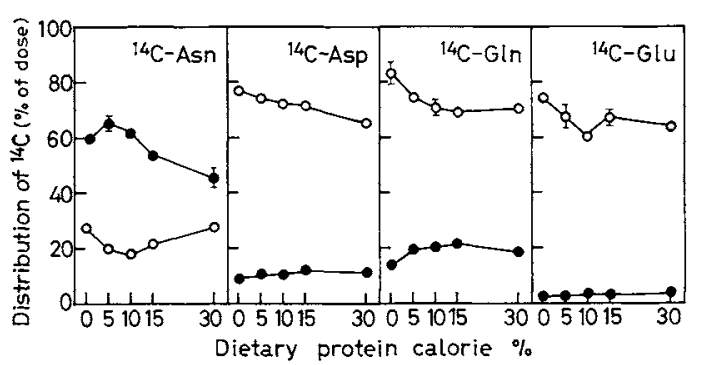

Fig. 3. Gross Distribution of Radioactivity in the Expired Carbon Dioxide and Body Protein Fraction from $\mathrm{L}-\left[\mathrm{U}-{ }^{14} \mathrm{C}\right]$ Asparagine and $\mathrm{L}-\left[\mathrm{U}-{ }^{14} \mathrm{C}\right]$ Glutamine Compared with that from $\mathrm{L}-\left[\mathrm{U}-{ }^{14} \mathrm{C}\right]$ Aspartic Acid and L-[U- $\left.{ }^{14} \mathrm{C}\right]$ Glutamic Acid.

Each value represents the mean for four rats, and the vertical bars indicate standard errors. The data for $\mathrm{L}-\left[\mathrm{U}_{-}{ }^{14} \mathrm{C}\right]$ aspartic acid and $\mathrm{L}-\left[\mathrm{U}-{ }^{14} \mathrm{C}\right]$ glutamic acid are cited from our previous papers. ${ }^{12,13)}$

$\mathrm{O}-\mathrm{O}$, expired ${ }^{14} \mathrm{CO}_{2} ;-$, body protein (the carcass plus liver).

dioxide but incorporated to a lesser extent into the body protein, the second includes nonessential amino acids which are used for body protein synthesis rather than for energy production, and the third includes essential amino acids that are preferentially used for body protein synthesis.

In this experiment, the metabolic fate of the carbon skeletons of asparagine and glutamine was subsequently examined under similar feeding conditions. As shown in Fig. 3, the expired ${ }^{14} \mathrm{CO}_{2}$ production and ${ }^{14} \mathrm{C}$-incorporation into the body protein from labeled asparagine and glutamine are compared with those from labeled aspartic acid and glutamic acid, the patterns of which were reported previously. ${ }^{12,13)}$ The values for the body protein fraction are the sum of the carcass and liver. The expired ${ }^{14} \mathrm{CO}_{2}$ output from labeled asparagine was markedly lower than that from labeled aspartic acid, glutamine and glutamic acid. Conversely, the incorporation of asparagine carbon into the body protein was significantly higher than that of aspartic acid, glutamine and glutamic acid. A greater amount of the asparagine carbon was incorporated into the body protein in the 0 to $10 \mathrm{PC} \%$ groups, but it decreased in the higher $\mathrm{PC} \%$ groups. The response pattern of asparagine to the dietary protein intake rather resembles that of serine, proline and glycine, showing one of the typical metabolic patterns of nonessential amino acids as just described. On the other hand, the oxidative degradation of ${ }^{14} \mathrm{C}$-glutamine was very high in all the dietary groups, and even in protein-depleted rats, the output of ${ }^{14} \mathrm{CO}_{2}$ was most increased. The utilization of labeled glutamine for body protein synthesis was particularly low in all the dietary groups. Thus, the carbon skeleton of glutamine as well as those of glutamic acid, aspartic acid and alanine, is utilized non-specifically as an energy source even at low protein levels of the diet.

In studies on amino acid nutrition, the importance of the nonessential amino acid, asparagine, for maximal growth in the rats has been reported by several workers. ${ }^{2-6)}$ Breuer et $a{ }^{3,4)}$ have reported that the omission of asparagine from an amino acid diet resulted in a significant decrease in the weight gain of yound rats, and the conservation of asparagine carbon was much higher than that of aspartic acid carbon when the labeled amino acid was given to rats. Rogers and Harper ${ }^{5)}$ have demonstrated that a growth stimulating effect of asparagine was observed in rats, but when glutamine was tested, there was no stimulation of weight gain. Moreover, impaired growth and protein synthesis in weanling rats fed on an asparagine-free diet was observed by Crosby and Cline. ${ }^{6)}$ Thus, it seems that asparagine is necessary for the optimum growth of rats during a period in which the rate of body protein synthesis increases and the demand on amino acids for anabolism is high. These nutritional phenomena may be closely related to the relatively high utilization of asparagine for body protein synthesis, although this nutritional beneficial effect of aspragine has not yet been confirmed. ${ }^{24)}$

In the course of degradation, the deamidation of asparagine to aspartic acid and of glutamine to glutamic acid are catalyzed by asparaginase and glutaminase, respectively, and they are quite specific to each other. Steward and Thompson ${ }^{25)}$ mentioned that the presence of asparaginase was to the lesser 
extent, and that glutaminase played a significant rule in animal tissues, while in plants both the deamidases which hydrolyze each amide were widespread. They also demonstrated that, because of the occurrence of intramolecular interaction between the amide and carboxyl group, asparagine rather than glutamine had the more anomalous structure, which is cyclic, so that the amide group of asparagine appears to be more stable than that of glutamine. Thus, it seems that glutamine is readily converted to glutamic acid in mammalian tissues, but asparagine to aspartic acid dose not occur. If asparagine is readily converted to aspartic acid, the carbon of labeled asparagine might be degraded more rapidly to the expired ${ }^{14} \mathrm{CO}_{2}$, because the ${ }^{14} \mathrm{CO}_{2}$ output from labeled aspartic acid was very high as described previously. ${ }^{13)}$ Although nutritional studies for the modulation of asparagine catabolic enzymes are limited, increasing activity of hepatic asparaginase by a high protein diet was found in rat ${ }^{26)}$ and chick $^{27)}$ livers.

Acknowledgment. The authors express their sincere thanks to Professor H. Nishi for his interest and support in this study. The authors are also indebted to Dr. M. Yamaguchi of the National Institute of Health and Nutrition for his suggestions.

\section{References}

1) A. Meister, "Biochemistry of the Amino Acids," Vols. I and II, Academic Press, New York, 1965.

2) D. S. Newburg and L. C. Fillios, J. Nutr., 109, 2190 (1979).

3) L. H. Breuer, Jr., W. G. Pond, R. G. Warner and J. K. Loosli, J. Nutr., 82499 (1964).

4) L. H. Breuer, Jr., R. G. Warner, D. A. Benton and J. K. Loosli, J. Nutr., 88, 143 (1966).

5) Q. R. Rogers and A. E. Harper, J. Nutr., 87, 267
(1965).

6) L. O. Crosby and T. R. Cline, J. Animal Sci., 37, 713 (1973).

7) H. Ishikawa, T. Aikawa and H. Matsutaka, J. Biochem., 71, 1097 (1972).

8) H. Tanaka, M. Yamaguchi and M. Kametaka, Agric. Biol. Chem., 38, 1113 (1974).

9) H. Tanaka, M. Yamaguchi and M. Kametaka, Agric. Biol. Chem., 39, 507 (1975).

10) H. Tanaka, M. Yamaguchi and M. Kametaka, Agric. Biol. Chem., 40, 1119 (1976).

11) H. Tanaka and M. Ogura, Agric. Biol. Chem., 44, 2343 (1980).

12) H. Tanaka, M. Ohyama and M. Ogura, Agric. Biol. Chem., 48, 2731 (1984).

13) H. Tanaka, Y. Nakatomi and M. Ogura, Agric. Biol. Chem., 51, 499 (1987).

14) H. Tanaka, Y. Nakatomi and M. Ogura, Agric. Biol. Chem., 51, 3087 (1987).

15) H. Tanaka, T. Fukushima, Y. Nakatomi and M. Ogura, Agric. Biol. Chem., 52, 811 (1988).

16) H. Tanaka, Y. Nakatomi, M. Mori and M. Ogura, Agric. Biol. Chem., 54, 2093 (1990).

17) H. Tanaka, Y. Nakatomi, K. Takahashi and M. Ogura, Agric. Biol. Chem., 55, 531 (1991).

18) M. Yamaguchi and M. Kandatsu, Agric. Biol. Chem., 37, 809 (1973).

19) D. S. Miller and P. R. Payne, Brit. J. Nutr., 15, 11 (1961).

20) H. Jeffay and J. Alvarez, Anal. Chem., 33, 612 (1961).

21) M. Kawakami and K. Shimura, Radioisotopes, 23, 15 (1972).

22) J. Folch, M. Lee and G. H. Sloane-Stanley, J. Biol. Chem., 226, 497 (1957).

23) M. Yoshida, "Design of Experiments of Animal Husbandry," Yokendo Co., Tokyo, 1975, p. 84.

24) Q. R. Rogers, D. M-Y. Chen and A. E. Harper, Proc. Soc. Exp. Biol. Med., 134, 517 (1970).

25) F. C. Steward and J. F. Thompson, Nature, 169, 739 (1952).

26) E. Bonetti, A Abbondanza, E. D. Corte and F. Stirpe, Biochem. J., 115, 597 (1969).

27) M. Penner and C. N. Coon, Poult. Sci., 59, 1109 (1980). 